\title{
A WINTER RECORD FOR THE SILVER-HAIRED BAT IN SASKATCHEWAN
}

\author{
R. MARK BRIGHAM, Department of Biology, University of Regina, Regina, \\ SK. S4S OA2
}

The Silver-haired Bat is widely distributed in Canada during the summer, and one of the more common species found in the Prairies. During winter, this normally migratory species has been recorded only from British Columbia, principally the southwestern corner of the province, ${ }^{2,3,4}$ although some individuals have been found in the southern interior in mid-winter, presumably hibernating. ${ }^{5}$

To my knowledge there are no winter records of Silver-haired Bats in Saskatchewan. The latest recorded date of capture that 1 am aware of for the province is 12 October. ${ }^{6}$ Early October is typically the end of the time of departure for migration in most parts of Canada. When I was called to a building to collect a bat on 21 December 1994 in Regina, I expected it to be a Big Brown Bat since this species regularly hibernates in buildings. It came as quite a surprise to find that it was a male Silver-haired Bat. The bat, which was in an emaciated condition, was found by the tenant of a building in the 2200 Block, Albert St. Based on the degree of ossification of the metacarpals, it was a juvenile born in the summer of 1994. I brought the bat into captivity and gave it food and water, but unfortunately it died two days later.

Whether it had been attempting to hibernate in the building or elsewhere in Regina or whether it was a very late migrant is not known. Big
Brown Bats which attempt to hibernate in buildings are often found in very poor condition flying around inside during the winter. This most commonly occurs after a change in weather (colder or warmer). ${ }^{7}$ Presumably, individual bats choose poor sites to hibernate and arouse to move. The weather turned quite warm on 20 December in Regina, which prompts me to speculate that the Silverhaired Bat had been hibernating in the area. I thank Shawne Arzab for bringing the bat to my attention.

1. VAN ZYLL DE JONG, C.G. 1985. Handbook of Canadian mammals. 2. Bats. National Museum of Natural Sciences, National Museums of Canada. 212 pp.

2. SCHOWALTER, D.B., W.J. DORWARD and J.R. GUNNSON. 1978. Seasonal occurrence of Silver-haired Bats (Lasionycteris noctivagans) in Alberta and British Columbia. Can. Field-Nat. 92:288-291.

3. COWAN, I. McT. 1933. Notes on the hibernation of Lasionycteris noctivagans. Can. Field-Nat. 47:74-75.

4. NAGORSEN, D.W. and R.M. BRIGHAM. 1993. The bats of British Columbia. UBC Press. 164 pp.

5. NAGORSEN, D.W., A.A. BRYANT, D. KERRIDGE, G. ROBERTS, A. ROBERTS and M.J. SARELL. 1993. Winter bat records for British Columbia. Northwest Nat. 74:61-66.

6. NERO, R.W. 1957. Saskatchewan Silver-haired Bat records. Blue Jay 15:38-41.

7. BRIGHAM, R.M. 1987. Winter activity by Eptesicus fuscus: the influence of energy reserves. Can. J. Zool. 65: 1240-1242. 